\title{
Female School Stipend Programs in Pakistan: A Case Study of Khyber Pakhtunkhwa Region
}

\author{
Rana Junaid Zahid \\ Sustainable Development Policy Institute (SDPI), Islamabad, Pakistan \\ Waqas Imran* \\ Idara-e-Talim-O-Agahi (ITA), Lahore, Pakistan \\ Shehryar Haq \\ Support to Life: International Humanitarian Aid, Turkey \\ Abeer Tahir \\ Sustainable Development Policy Institute (SDPI), Islamabad, Pakistan
}

\begin{abstract}
The study was conducted to assess the success of a stipend program in girls' schools launched by Khyber Pakhtunkhwa (KP) government about three years ago. The program aims to increase the female enrolment and reduce gender parity in education. A mix methodology employed. Study show that program did not put any impact on girls' enrolment Khyber Pakhtunkhwa region. Instead different other observations affecting the enrolment ratio were noted. To further explore the other factors causing no increase in girls' enrolment and to test the results of the study, a primary study was done using qualitative method. Grounded theory was built and tested. Both the deductive and in-deductive approaches have been used to strengthen the study. Results of the study interestingly show that, it is not the money but culture which is the real hurdle in increase in enrolment ratio. Most of the parents do not allow girls to go to school due to cultural barriers. Awareness campaigns need to be designed for the parents. Keywords: Enrolment, Government Schools, Gender, Pakistan Social and Living Standards Measurement Survey (PSLMS), Logistic Regression, Pakistan.
\end{abstract}

DOI: $10.7176 /$ RHSS/10-9-03

Publication date:May $31^{\text {st }} 2020$

\section{Introduction}

Three million school-going children, including two million girls, are estimated to be not enrolled in Khyber Pakhtunkhwa (KP). Similarly, about 30\% women are literate. The provincial government has though made a significant improvement in governance by computerizing the literacy records throughout the province, a lot more needs to be done. The provincial government designed a stipend program to help the poor parents to send their daughters to schools with the target to increase the girls' enrolment in secondary schools. Different options were looked into for the girls, who were usually dropped out of schools while studying in the grades between 5 to 10 . This included the proposal of a profound structure that will increase the efficiency of the stipend on girls' participation rate. A proposal on eligibility criterion and the monitoring mechanism was also part of the said proposal. The existing system for the payment of stipend via Post Office had flaws and hence an electronic payment method was designed (Development Pathways 2015). The International Development Association (IDA) financed the Bangladesh Female Secondary School Assistance Program (FSSAP) that was initiated in 1993. In this program, access to secondary education for girls was intended to improve by providing tuition stipends. The project covered 121 out of 507 sub-districts of Bangladesh. Girls' enrolment in secondary schools increased from 1.1 million in 1991 to 3.9 million in 2005. Hence Bangladesh completed one of its Millennium Development Goals (gender parity in education) on time. Female enrolment, as a percentage of total enrolments, increased from 33\% in 1991 to $48 \%$ in 1997 and almost 55\% in 2008. The indirect benefits of the project were manifold, including reduced early-age marriages and fertility rates, better nutrition and more female employment with higher incomes.

A considerable progress is visible in enrolment, ratio of female-to-male, and literacy rates (Annual School Statistics, 2015). The stipend policy has been termed as one of the main government initiatives to achieve the targets. The elementary and secondary education department of Khyber Pakhtunkhwa has been running the stipend program since 2006. The program had three different streams, i.e Provision of stipend initiated in seven districts of the province and later to the entire province, excluding Torghar and Kohistan. The girls from grade 6th to 10th were entitled to Rs200 monthly stipend under this program. On the other hand, Rs1500 per month was given to primary schoolgirls and Rs 2,000 per month was given to schoolgirls in grade 6th to 10th in Torghar and Kohistan as per the geographical disadvantage of these two regions. A special initiative program was launched in 20132014. A stipend of Rs400 per month was paid to girl students of class 6 th and above at middle level, who secured $80 \%$ attendance. The facilities are extended to seven districts (Hangu, Peshawar, Bannu, Lakki Marwat, D.I.Khan, 
Shangla, and Nowshera). These districts have been selected on the basis of Net Enrolment Ratio (NER). The purpose of this gender specific program is to remove gender disparity in KP education system.

This study focuses on whether the female enrolment has enhanced as a result of the stipend policy or not. It also highlights the other factors impacting the girls' enrolment. Major objectives of the study are to 1) to analyze the impact of stipend program on girls' enrolment in KP, and, 2) to identify the different factors affecting the girls' enrolment in KP.

\subsection{Literature Review}

Literacy rate is used to measure the level of prosperity. In this regard, special stress is laid upon imparting education to the segment of the society that is considered marginalized. In Pakistan, female population comprises around $51 \%$ of the total. Hence female education means educating more than half of the population and a larger impact on the output (Elborgh-Woytek, et al. 2013).

Education is equally important for both males and females. It also imparts significant role in fostering fiscal activities and developing the well-being of people (Fergus 2012).

In developing countries, female enrolment rate is usually lower than that of male especially in rural areas (Afzal et al. 2013). Therefore, in order to bridge this gender gap, secondary education of girls should be given special attention. In this regard, it is imperative to highlight the factors obstructing female education.

One of the reasons behind least priority to girl's secondary education might be religious beliefs and early marriages or their unproductive role in terms of financial support to family (Atchoarena and Gasperini 2003).

The parents in the KP hesitate to get their children enrolled mainly due to poverty and security concerns. In the past, many girl schools had been blown by the terrorists. Besides, a traditional and conservative social set-up in KP also tends to symbolize the boundary walls as protection especially for the girls. It is the responsibility of the government to provide comfortable and socially-acceptable environment to the students so that the learning and teaching can be a healthy and pleasurable activity for the students and teachers respectively (Williams, et al., 2011).

In KP, female literacy rate is only $35 \%$. There are many reasons for low enrolment of females such as poverty and economic issues, inadequate school infrastructure, gender bias, and lack of qualified teachers in girl schools. The age of the child, parents' schooling particularly the mothers, per capita income of the household head and distance to school are the explanatory variables for computing the probability of female enrolment at the primary school level (Toor \& Parveen 2004).

KP government has earmarked a monthly stipend of Rs200 for every schoolgirl at primary level to increase their enrolment. This project can prove to be the game-changer for the province as it was in case of Bangladesh where literacy rate is $77.1 \%$ among males aging between 15 to 24 years and $80.4 \%$ among females of the same age group (Khan 2014).

\section{Material and Methods}

Pakistan Social and Living Standards Measurement Survey (PSLMS), conducted by Pakistan Bureau of Statistics (PBS), provide the information of children currently enrolled at public and private educational institutions. A cross section of pooled sample from two rounds of PSLMS (conducted in 2012-11 and 2014-15), was compiled to analyze the enrolments before the start and during the execution of the stipend program. Both the PSLMS rounds (2010-11 \& 2014-15) provide the district level estimation.

In order to see some sort of midline impact of stipend program intervention on current enrolment in public educational institutions and to observe the situation of enrolments before and after the initiation of stipend program (2012-13), PSLMS 2010-11 has considered data before the start (base year) of stipend program and PSLMS 201415 as the current data. Both these surveys provide the district level socioeconomic indicators. All the female children aging 10-16 years from Khyber Pakhtunkhwa (KP) region makes our target population. Summary of both the samples for KP region is provided in Table 1 (Annexure-I).

\subsection{Data Limitations}

Multiple sections of the questionnaires were merged together to have a cross section analysis. 'Employment' section, providing information about working status and income of individuals, is limited to a population of 10 years and above. 'Education' section asks about learning skills from population starting from 10 years and above ages, education attainment and problems with educational institutions from population aged 4 years and above. Cross section analysis was executed for 10 years and above to account for the impact of income, parental education attainment, stipend program initiation on current enrolment.

\subsection{Response variable}

Enrolment status of female children (10-16 years) is considered the major outcome. Stipend program (2012-13) was initiated to improve the access to schools by motivating the female children with stipend to come to school. 
Our main response variable comes from the status of current enrolment of children (10-16 years). Two of the questions address this issue in the PSLMS household questionnaires. One question asks about whether the individual of the household currently studying at any educational institution or not. Another question asks about type of educational institutions wherein the indivildual of the household is currently studying. Those children (1016 years) who are currently studying at public institutions are recognized as currently enrolled students at public educational institutions and were coded as ' 1 ' and ' 0 ' otherwise.

\subsection{Explanatory variables}

Definitions of independent explanatory variables are provided in table 2 (Annexure-II). Variables are selected on basis of literature. A good number of studies have provide base to select these indicators. Conelly et al (2003) has used parental education, income as independent variable to show its impact on enrollment of 10 to 18 years students. Chaudhury et al., (2010) and Khandker, et al., (2003) predicts the female school enrollment effected by stipend program by using household characteristics.

\subsection{Statistical Model}

Dey et al., 1993, provided a brief of statistical models to be used for predicting schooling. This study focuses on prediction of school enrolment of female children affected by government's initiative of student stipend program and some parental characteristics. Based on nature of our response variable i.e., whether the child is enrolled or not, Binary Logistic Regression model is adopted to account for impact of explanatory variables on current enrolment status. General form of the model is given below:-

$$
\operatorname{logit}_{(p)}=\log \left(\frac{p}{1-p}\right)=\beta_{o}+\beta_{1} X_{1}+\beta_{2} X_{2}+\beta_{3} X_{3}+\cdots
$$

Here, 'p' is the probability that an individual (10-16 years) is currently studying at public educational institution. ' $\beta \mathrm{o}$ ' is the intercept; $\beta 1, \beta 2, \beta 3$, are the coefficients (effects) of predictors (explanatory variables) and ' $\mathrm{X} 1, \mathrm{X} 2$, $\mathrm{X} 3, \ldots .$. " are the explanatory variables with levels (variable categories). Hosmer and Lemeshow test has adopted to test that whether our set of predictors fit wells to statistical model or not.

\section{Results}

\subsection{Background characteristics of respondents}

All the selected background characteristics are found statistically associated with enrolment status of female children before and after the intervention period (initiation of stipend program). [see Table 3; Annexure-III]

Enrolment improves after the stipend program for those female children, who belong to rural areas and with parents having maximum primary level education. However, enrolment does not increase in case of those female children, who belong to parents educated above primary level of education. Children living in urban areas are left disadvantaged from the stipend program, as their enrolment rate do not improve after (in 2015) the program intervention Khyber Pakhtunkhwa. [see Table 3; Annexure-III]

\subsection{Factors Affecting Girls Enrolment}

Table 4 (Annexure-IV) provides the odds ratio explaining the chances of female children currently studying at public educational institutions. Unadjusted odds provide the evidence that each of predictors is important $(\mathrm{p} \leq 0.001)$ to influence the enrolment. Interestingly, adjusted model shows that females studying before (2010-11) the intervention period (2012-13) are 1.2 times (Adjusted: OR 1.227, $\mathrm{p} \leq 0.001$ ) likely to continue their schooling as compared to those who are currently studying after (2014-15) the intervention period (2012-13). Children moving towards the age of 16 are 0.38 times less likely to be in schools as compared to students aged $\leq 13$ years. A statistical evidence of 0.3 times (Adjusted: OR 0.298, $\mathrm{p} \leq 0.000$ ) fewer chances of female enrolment from rural areas emerges as compared to those from urban areas.

We have seen that the Richest ones have 0.9 times (Adjusted: OR 0.873, $\mathrm{p} \leq 0.05$ ) less chances to have female children at public schools as compared to poorest children. Social status of parents put positive impact on enrolment of their children. As soon as education of parents improves the chances of being enrolling to public institutions improves. Mothers having education above primary level are 3.1 times (Adjusted OR 3.071, $\mathrm{p} \leq 0.05$ ) more likely to have female children enrolled at public institutions as compared to uneducated mothers. Similarly, highly educated fathers give more importance to female education. There are 2.6 times (Adjusted: OR 2.640, $\mathrm{p} \leq 0.001$ ) more chances of female children, with highly educated fathers, currently studying at public institutions as compared to those with uneducated fathers.

Model Fitting As p-value for Hosmer and Lemeshow is greater than 5\% level of significance, therefore, our claim of non-suitability of predictors to model is rejected and we conclude that all of explanatory variables predict the enrolment well. 


\section{Grounded Theory}

Generally enrollment is known to be a function of three domains including; 1 ) demand side i.e. role of parents to benefit their children with staying them at educational institution; 2) supply side i.e., quality and availability of educational institutions most common at developing countries and 3) Government policy toward education i.e, new initiatives to motivate children and parents for enrolling to schools (Connelly, et al., 2003; Binder, 1999). It has been observed that lack of financial resources is not the major factor in causing low enrolment of girls in the province. There are other factors that highly influence the girl's enrolment.

\subsection{Ground evidence}

Once from data hypothesis has been rejected, now to fulfill the second objective, a primary study has been conducted in eight different districts of the province. Five in-depth interviews have been held in each district to know the core reason of the rejection of our hypothesis.

According to in-depth interviews held with women from different social and economic backgrounds of province Khyber Pakhtunkhwa, the main reasons that stop parents from sending their girls to schools included poverty, security of girls in Pashtun culture, religious and social conservatism of the community and the mindset that the girls need not to work to earn, hence they need not to be educated. Similarly, the parents deem education as unnecessary for the girls on the basis of their religious beliefs that the girls should stay at home. Some of the parents think that girls should be married early as it is an obligation by religion.

The above-mentioned social factors are also hindrance in the success of the stipend program. Similarly, the disparity in education has also been more or less the same despite the fact that the girl schools have better percentage of basic facilities.

\section{Discussion}

The KP government has declared educational emergency in the province. A new concept of Independent Monitoring Units (IMUs) is in place to ensure teachers and students attendance in schools. Enrolment campaign Parho Aur Zindagi Badlo (means Study and Change Life) got underway in the province. This campaign has resulted in the enrolment of approximately 0.3 million children. The provincial government is all set to pay a monthly stipend of Rs 200 to schoolgirls so that the parents are encouraged to educate their daughters (Ahmed 2015).

Shah (2015) quoted in her article as saying: A 9th grade girl namely Mahnoor says these two hundred rupees can be a reason for many girls from the poor families, who are still managing to continue their studies. She says that she saves this monthly stipend and uses it to buy stationery. She adds that many poor parents already doing an extraordinary job by sending their girls to schools amid security concerns and unfavorable circumstances. Anwar Sultana, the principal of the school, says that enrolment has improved in her school and this monthly stipend seems to be a motivational factor. Some girls use this money to buy their stationery while others for paying fare to come to school without burdening their parents (Shah, 2015). Interestingly, enrolment has been affected nonpositively by the stipend program with its more chances for children not benefited with this program.

It is learnt that as soon as the age of child increases, the chances of enrolment decreases. It gives an insight to low motivation toward schooling for younger children. Low chances of enrolment at rural areas focuses on the poor schooling at less developed areas of the country.

Socioeconomic status put light on its impact on enrolment of children. Household annual income levels provide the significant but negative impact on enrolment. We have observed that as soon as income levels improve, the chances of being enrolled at public institution did not improve. It enlightens the parents preferring other than public educational institutions for their daughters. Education of parents gives evidence of more female enrolments for more educated parents.

Our investigation concluded that girl students are more likely to stay away from schools, who are from rural background, belong to the poor social strata, and uneducated families. The stipend program has not proven to be beneficial to improve chances of female children being enrolled to public institutions. This factor did not show any positive impact, independently, to improve female access to schools. Contribution of background factors like annual income of households and social status of parents also emerge as important to consider while planning for improving the access to education especially for targeting the females from rural areas.

\section{Recommendations}

The inter-departmental coordination including Finance, Planning and Development, Pakistan Post Office, Accountant General Office and EDOs should be strengthened. There is no complaint registration mechanism in case the stipend money disbursement is delayed. Hence the transaction cost of grievance redressed should be reduced through IT enabled services. In view of this study, certain practicable recommendations are being presented here that can help improve the efficiency and the working of the stipend policy. The will of government towards an educated and female empowered society must be appreciated. After the 18th Constitutional 
Amendment, the provinces are autonomous in communicating, coordinating and making pacts/memorandums with donors (countries as well as agencies). The federal government should project the image of provinces that spend heavily on education so as to make it as an incentive.

- The provincial government should increase the stipend amount to a substantial and handsome figure, designed for school enrolment while eliminating gender disparity in education.

- Broader awareness programs must be arranged for parents to communicate them the importance of their daughters' education in view of economic and human development.

- $\quad$ The number of female institutions of all levels (primary, secondary, higher secondary) must be increased especially in rural areas so it will be accessible to the rural females.

- The number of female teachers should also be increased in order to maintain the student-to-teacher ratio or improve it so that it can attract parents to send their girls to school.

- $\quad$ Although it has been observed that the basic facilities in girls' schools are better than the boys' schools, yet it should be improved further as the parents of the girls are more specific and conscious of the presence of the basic facilities in the school.

- The government should run a comparative analysis, with baseline, every year to see the success of the program.

- $\quad$ The government needs to run multiple programs parallel to each other in order to achieve desired results. In this way, the province and hence the country would subsequently be fulfilling its commitments towards development of social sectors particularly the education (the Global Development Summits 1995, 2000 and the Sustainable Development Goals 2000-15).

\section{References}

1. Afzal, M., Butt, A. R., Akbar, R. A., \& Roshi, S. (2013). Gender Disparity in Pakistan: A Case of Middle and Secondary Education in Punjab. Journal of Research, 7(2), 113-124.

2. Ahmed, Z., (2015). PTI achieves significant improvement in governance. http://epaper.brecorder.com/m/2015/05/28/12-page/507798-news.html

3. Annual School Census, (2015). Elementary \& Secondary Education Department Government of Khyber Pakhtunkhwa.[online] Available at http://www.kpese.gov.pk/SchoolStatistics.html [Accessed 07-05-2016]

4. Atchoarena, D., \& Gasperini, L. (2003). Education for Rural Development towards New Policy Responses. International Institute for Educational Planning (IIEP) UNESCO. 7-9 rue Eugene-Delacroix, 75116 Paris, France. Retrieved from http://files.eric.ed.gov/fulltext/ED499625.pdf

5. Binder, M. (1999). Community effects and desired schooling of parents and children in Mexico. Economics of Education Review, 18(3), 311-325.

6. Chaudhury, N., \& Parajuli, D. (2010). Conditional cash transfers and female schooling: the impact of the female school stipend program on public school enrolments in Punjab, Pakistan. Applied Economics, 42(28), 3565-3583.

7. Chaudhury, N., \& Parajuli, D. (2010). Conditional cash transfers and female schooling: the impact of the female school stipend program on public school enrolments in Punjab, Pakistan. Applied Economics, 42(28), 3565-3583.

8. Development Pathways (2015). KP Education Sector Program, Pakistan, [online] Available at http://www.developmentpathways.co.uk/projects/adolescent-economic-empowerment-opportunities-2 [Accessed 07-05-2016]

9. Dey, E. L., \& Astin, A. W. (1993). Statistical alternatives for studying college student retention: A comparative analysis of logit, probit, and linear regression. Research in higher education, 34(5), 569-581.

10. Elborgh-Woytek, M. K., Newiak, M. M., Kochhar, M. K., Fabrizio, M. S., Kpodar, K., Wingender, M. P., ... \& Schwartz, M. G. (2013). Women, work, and the economy: Macroeconomic gains from gender equity. International Monetary Fund.

11. Fergus, L. (2012, September). Prevention of violence against women and girls. In UN Women In cooperation with ESCAP, UNDP, UNFPA, UNICEF and WHO Expert Group Meeting: Prevention of violence against women and girls. 2012. Bangkok, Thailand 17-20 September 2012.

12. Khan, A., (2014). Building Bridges. [Online] Available at http://ayeshazeekhan.blogspot.com/2014/07/emphasis-on-education-in-kpk.html

13. Khandker, S., Pitt, M., \& Fuwa, N. (2003). Subsidy to promote girls' secondary education: the female stipend program in Bangladesh.

14. Pakistan Bureau of Statistics, Pakistan Social and Living Standards Measurement Survey (PSLMS) at http://www.pbs.gov.pk/content/pakistan-social-and-living-standards-measurement

15. Shah, S.Q., (2015). [Online] Available at http://www.dawn.com/news/1161230

16. Toor, I. A., \& Parveen, R. (2004). Factors influencing girls' primary enrolment in Pakistan.

17. Williams, K. C., \& Williams, C. C. (2011). Five key ingredients for improving student motivation. Research 
in Higher Education Journal, 12, 1.

Annexure-I

Table 1

Summary of samples

\begin{tabular}{|l|c|c|}
\hline Samples & $\mathbf{2 0 1 0 - 1 1}$ & $\mathbf{2 0 1 4 - 1 5}$ \\
\hline Primary Sampling Units (blocks) & 849 & 881 \\
\hline Secondary Sampling Unit (households covered) & 12552 & 13680 \\
\hline Target population (10-16 years) - Both Sexes & 17506 & 18419 \\
\hline
\end{tabular}

Annexure-II

Table 2

Variable definition

\begin{tabular}{|c|c|c|}
\hline Variables & Definition & Levels \\
\hline \multirow{2}{*}{ Age of Child } & \multirow{2}{*}{ Age of individual in completed years } & $10-12$ \\
\hline & & $13-16$ \\
\hline \multirow{2}{*}{ Region } & \multirow{2}{*}{ Type of place of residence } & Urban \\
\hline & & Rural \\
\hline \multirow{5}{*}{ Income Strata } & \multirow{5}{*}{$\begin{array}{l}\text { It is constructed from annual incomes reported by all eligible individuals (10 } \\
\text { years and above) of household. } \\
\text { Net income excludes taxes and employer's employee's contribution to } \\
\text { social security, benevolent funds, etc. Cash bonuses, gratuities and other } \\
\text { cash allowances are included. Income from rent, interest and dividends is } \\
\text { excluded when received separately from net pay. } \\
\text { With lowest covering bottom } 20 \% \text { and highest covering top } 20 \% \text { of the } \\
\text { household population. }\end{array}$} & Poorest \\
\hline & & Poor \\
\hline & & Middle \\
\hline & & Rich \\
\hline & & Richest \\
\hline \multirow{3}{*}{$\begin{array}{l}\text { Mother's } \\
\text { Education } \\
\text { Level }\end{array}$} & \multirow{3}{*}{$\begin{array}{l}\text { Educational years successfully completed by mothers. It is divided into } \\
\text { uneducated (completed } 0 \text { years of schooling); primary (completed } 1-5 \text { years } \\
\text { of schooling and higher (completed } 6 \text { years and above years of schooling) }\end{array}$} & Uneducated \\
\hline & & Primary \\
\hline & & Higher \\
\hline \multirow{3}{*}{$\begin{array}{l}\text { Father's } \\
\text { Education } \\
\text { Level }\end{array}$} & \multirow{3}{*}{$\begin{array}{l}\text { Educational years successfully completed by mothers. It is divided into } \\
\text { uneducated (completed } 0 \text { years of schooling); primary (completed } 1-5 \text { years } \\
\text { of schooling and higher (completed } 6 \text { years and above years of schooling) }\end{array}$} & Uneducated \\
\hline & & Primary \\
\hline & & Higher \\
\hline \multirow{2}{*}{$\begin{array}{l}\text { Stipend } \\
\text { Program }\end{array}$} & \multirow{2}{*}{$\begin{array}{l}\text { Period 2010-11 considered as period before program initiated and 2014-15 } \\
\text { considered as program in progress. }\end{array}$} & $\begin{array}{l}\text { Program in } \\
\text { progress }\end{array}$ \\
\hline & & $\begin{array}{l}\text { Program not } \\
\text { started }\end{array}$ \\
\hline
\end{tabular}

Table 3

Annexure-III

Distribution of female students currently studying at educational institutions

\begin{tabular}{|c|c|c|c|c|c|c|c|}
\hline \multirow[b]{2}{*}{ Variable } & \multirow[b]{2}{*}{ Levels } & \multicolumn{3}{|c|}{ Before Stipend Program (2011) } & \multicolumn{3}{|c|}{ After Stipend Program (2015) } \\
\hline & & $\begin{array}{c}\text { Not } \\
\text { Enrolled }\end{array}$ & Enrolled & Sample & $\begin{array}{c}\text { Not } \\
\text { Enrolled }\end{array}$ & Enrolled & Sample \\
\hline \multirow[t]{3}{*}{ Age of Child } & $10-12$. & $37.1 \%$ & $62.9 \%$ & 3856 & $39.4 \%$ & $60.6 \%$ & 3694 \\
\hline & $13-16$ & $55.7 \%$ & $44.3 \%$ & 4328 & $60.5 \%$ & $39.5 \%$ & 4432 \\
\hline & $\chi^{2}$ (p-value) & \multicolumn{2}{|c|}{$\mathrm{p} \leq 0.000$} & & \multicolumn{2}{|c|}{$\mathrm{p} \leq 0.000$} & \\
\hline \multirow[t]{3}{*}{ Place of Residence } & Urban & $23.2 \%$ & $76.8 \%$ & 647 & $29.4 \%$ & $70.6 \%$ & 1940 \\
\hline & Rural & $52.9 \%$ & $47.1 \%$ & 7537 & $52.8 \%$ & $47.2 \%$ & 6186 \\
\hline & $\chi^{2}$ (p-value) & \multicolumn{2}{|c|}{$\mathrm{p} \leq 0.000$} & & \multicolumn{2}{|c|}{$\mathrm{p} \leq 0.000$} & \\
\hline \multirow[t]{4}{*}{ Income Strata } & Poor & $60.4 \%$ & $39.6 \%$ & 1106 & $55.6 \%$ & $44.4 \%$ & 1025 \\
\hline & Middle & $69.6 \%$ & $30.4 \%$ & 448 & $60.8 \%$ & $39.2 \%$ & 500 \\
\hline & Rich & $63.8 \%$ & $36.2 \%$ & 1143 & $54.1 \%$ & $45.9 \%$ & 907 \\
\hline & $\chi^{2}$ (p-value) & \multicolumn{2}{|c|}{$\mathrm{p} \leq 0.003$} & & \multicolumn{2}{|c|}{$\mathrm{p} \leq 0.050$} & \\
\hline \multirow{4}{*}{$\begin{array}{l}\text { Household } \\
\text { (Mother) } \\
\text { Level }\end{array}$} & Uneducated & $51.2 \%$ & $48.8 \%$ & 7990 & $48.2 \%$ & $51.8 \%$ & 7848 \\
\hline & Primary & $26.3 \%$ & $73.7 \%$ & 133 & $20.4 \%$ & $79.6 \%$ & 137 \\
\hline & Higher & $17.6 \%$ & $82.4 \%$ & 51 & $20.6 \%$ & $79.4 \%$ & 141 \\
\hline & $\chi^{2}$ (p-value) & \multicolumn{2}{|c|}{$\mathrm{p} \leq 0.000$} & & \multicolumn{2}{|c|}{$\mathrm{p} \leq 0.000$} & \\
\hline
\end{tabular}




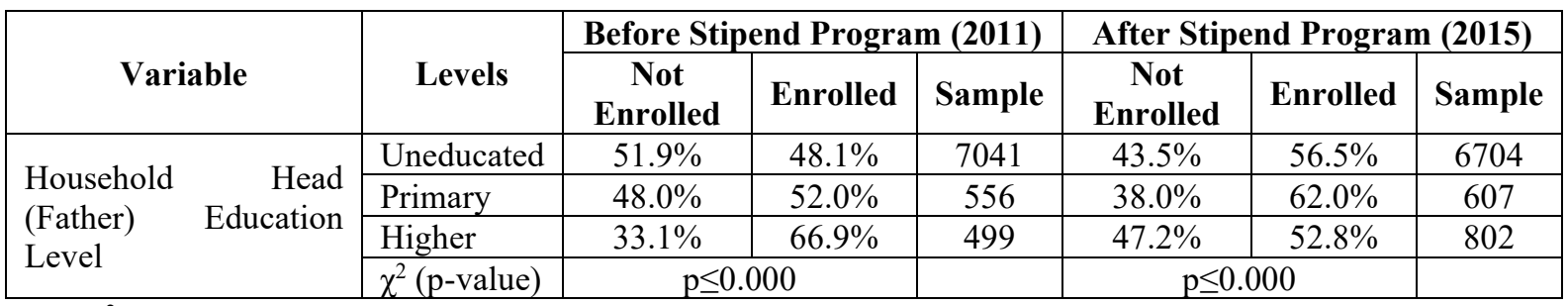

Note: $\chi^{2}$ (p-value) is the test for independent association between background variables and enrollment

Annexure-IV

Table 4

Odds of female children currently enrolled to educational institutions by background characteristics

\begin{tabular}{|c|c|c|c|}
\hline Predictors & Levels & Unadjusted Odds & Adjusted Odds \\
\hline \multirow[b]{2}{*}{ Stipend Program } & Program in progress & 1.000 & 1.000 \\
\hline & Program not started & $\begin{array}{c}1.144 * * \\
(1.076-1.217)\end{array}$ & $\begin{array}{c}1.227 * * \\
(1.087-1.384)\end{array}$ \\
\hline \multirow[b]{2}{*}{ Age of Child } & $10-12$. & 1.000 & 1.000 \\
\hline & $13-16$ & $\begin{array}{c}0.448 * * \\
(0.420-0.477)\end{array}$ & $\begin{array}{c}0.378 * * \\
(0.336-0.426) \\
\end{array}$ \\
\hline \multirow[b]{2}{*}{ Region } & Urban & 1.000 & 1.000 \\
\hline & Rural & $\begin{array}{c}0.344 * * \\
(0.314-0.377)\end{array}$ & $\begin{array}{c}0.298^{* *} \\
(0.226-0.392)\end{array}$ \\
\hline \multirow{3}{*}{ Income Strata } & Poor & 1.000 & 1.000 \\
\hline & Middle & $\begin{array}{c}0.747 * * \\
(0.637-0.876)\end{array}$ & $\begin{array}{c}0.703 * * \\
(0.594-0.831)\end{array}$ \\
\hline & Rich & $\begin{array}{c}0.943 \\
(0.834-1.067) \\
\end{array}$ & $\begin{array}{c}0.873^{*} \\
(0.765-0.996) \\
\end{array}$ \\
\hline \multirow{3}{*}{ Household Head (Mother) Education Level } & Uneducated & 1.000 & 1.000 \\
\hline & Primary & $\begin{array}{c}3.244 * * \\
(2.442-4.308)\end{array}$ & $\begin{array}{c}0.983 \\
(0.480-2.010)\end{array}$ \\
\hline & Higher & $\begin{array}{c}4.001 * * \\
(2.801-5.714)\end{array}$ & $\begin{array}{c}3.071 * \\
(1.228-7.680)\end{array}$ \\
\hline \multirow{3}{*}{ Household Head (Father) Education Level } & Uneducated & 1.000 & 1.000 \\
\hline & Primary & $\begin{array}{c}1.206^{*} \\
(1.070-1.360)\end{array}$ & $\begin{array}{c}1.526^{* *} \\
(1.239-1.879)\end{array}$ \\
\hline & Higher & $\begin{array}{c}1.792 * * \\
(1.593-2.017)\end{array}$ & $\begin{array}{c}2.640 * * \\
(2.006-3.475) \\
\end{array}$ \\
\hline \multicolumn{3}{|l|}{ Intercept } & 3.223 \\
\hline \multicolumn{3}{|l|}{ Hosmer \& Lemeshow Test } & $3.566(\mathrm{p} \leq 0.894)$ \\
\hline \multicolumn{3}{|l|}{ R-Square (Nagelkerke) } & 0.116 \\
\hline
\end{tabular}

( ) In parenthesis is $95 \%$ confidence interval; (*) provides hypothesis testing with $5 \%$ level of significance and $(* *)$ gives hypothesis testing with $1 \%$ level of significance. 